\section{SYNTACTIC PATTERNS OF ZHUANG IDIOMS}

\author{
Somsonge Burusphat ${ }^{1}$ \\ Qin Xiaohang ${ }^{2}$
}

\begin{abstract}
This paper describes idioms of the northern Zhuang language. Zhuang idioms are analyzed into two major types, based on syntactic structure: trisyllabic idioms and polysyllabic idioms. Tri-syllabic idioms are short, fixed common expressions consisting of a single predicate. The polysyllabic idioms comprise tetrasyllabic idioms, pentasyllabic idioms, hexasyllabic idioms, and heptasyllabic idioms. The polysyllabic idioms display four syntactic patterns, i.e., serial pattern, causative pattern, topicalized pattern, and condensed pattern. Semantically, the meanings of Zhuang idioms are not the sum of their component part but must be metaphorically interpreted as a whole. The function of Zhuang idioms is to increase effectiveness and rhetorical force in oral and literary communication.
\end{abstract}

\section{Zhuang language}

This paper describes idioms of the Zhuang language spoken by the Zhuang people in China. ${ }^{3}$ According to Qin (1995), the Zhuang comprise the largest ethnic minority in China, with a population of 17 millions as of 2001. The Zhuang people are found

\footnotetext{
${ }^{1}$ Professor, Research Institute of Languages and Cultures of Asia, Mahidol University.

${ }^{2}$ Professor, Central University for

Nationalities, Beijing, PR China

${ }^{3}$ An overview of the Zhuang language is given in Luo (2008).
}

mainly in Guangxi Zhuang Autonomous Region and in Wenshan Zhuang-Miao Autonomous Prefecture in Yunnan Province. In addition, there are Zhuang scattered throughout Lianshan Zhuang-Yao Autonomous County in Guangdong Province, Qiandongnan Miao-Dong Autonomous Prefecture in Guizhou Province, and Jianhua Yao Autonomous County in Hunan Province. Moreover, the Zhuang language is also spoken by people in the southern part of Guizhou and the northern part of the Democratic Republic of Vietnam. The Zhuang language belongs to the Tai language group of the Tai-Kadai language family. It is divided into two main varieties, the northern variety and the southern variety. This paper describes idioms that occur in the northern variety of the Zhuang language.

\section{Methodology}

The first step was to define idioms. Crystal (1985: 152) defines idiom as follows:
A sequence of words which is semantically and often syntactically restricted, so that they function as a single unit. From a semantic viewpoint, the meanings of the individual words cannot be summed to produce the meaning of the 'idiomatic' expression as a whole. From a syntactic viewpoint, the words often do not permit the usual variability they display in other contexts.

Based on the definition above, a Zhuang idiom is defined as a word group whose meaning cannot be predicted simply from the meanings of its constituent parts. Zhuang idioms are similar to Zhuang proverbs. The difference lies in the syntactic structure. That is, Zhuang idioms are a single word group typically composed of nouns, verbs, or adjectives, while Zhuang 
proverbs contain two or more compound sentences or clauses, most of which are coordinate. Rhyme is a common feature of Zhuang proverbs, whereas it is not typical of Zhuang idioms. The contrast between Zhuang idioms and Zhuang proverbs is exemplified in Table 1 .

Table 1: Contrastive examples of Zhuang idioms and Zhuang proverbs

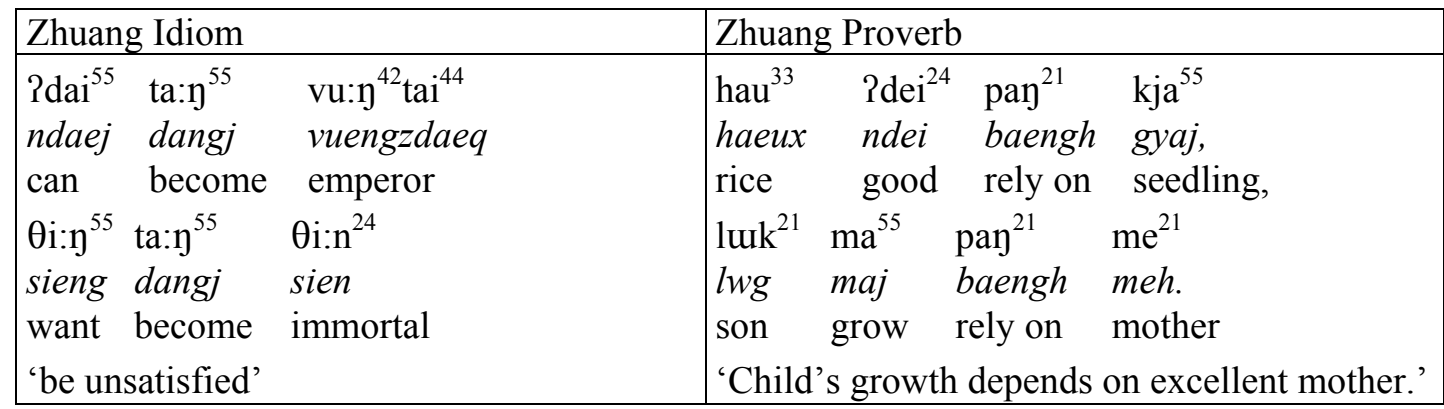

The Zhuang idiom has two clauses construed as a single word group which conveys a metaphorical meaning. The Zhuang proverb has two compound clauses which are coordinative without an overt conjunction. The last word of the fist clause, $\left[\mathrm{kja}^{55}\right]$ gyaj 'seedling', rhymes with the second word of the second clause, $\left[\mathrm{ma}^{55}\right] \mathrm{maj}$ 'grow'.

The second step consisted of data compilation. The Zhuang data were drawn from the second author who is a native speaker of the Zhuang dialect of Hawyiengz, Mashan County, Guangxi Zhuang Autonomous Region. The data were checked with other native speakers from the same area. The third step involved transcribing the compiled Zhuang idioms in phonetic symbols and Zhuang romanization. The word-by-word translation was based on the Northern Zhuang-Chinese-Thai-English Dictionary (Burushpat and Qin 2006). Additionally, since Zhuang idioms evince constructions that are not susceptible to regular or predictable semantic interpretation, a non-literal semantic interpretation, or the meaning of the idiomatic expression as a whole, is provided. The final step was the categorization of Zhuang idioms into types using the structuralist approach defined by Trask (1993: 262) as "Any approach to linguistic description which views the grammar of a language primarily as a system of relations." 


\section{Idiom types}

This study approaches Zhuang idiom formation from a synchronic perspective. Based on the internal syntactic structure, Zhuang idioms are analyzed into two major types, trisyllabic idioms and polysyllabic idioms. Trisyllabic idioms are distinguished from polysyllabic idioms in that the former have simple syntactic structures, that is, a verb and an object, whereas the latter show more complex syntactic patterns.

\section{Trisyllabic idioms}

Tri-syllabic idioms are short, fixed common expressions used by Zhuang people in everyday life; thus they may be also designated customary phrases. ${ }^{4}$ Trisyllabic idioms consist of a single predicate, i.e., a verb and an object, that convey a figurative or metaphorical meaning. Customary phrases are terse and vivid, and their metaphors are appropriate, popular, and interesting, as exemplified in Table 2.

\footnotetext{
${ }^{4}$ The term phrase as used in this paper refers to any string of words under consideration, regardless of its syntactic status. It is equivalent to the alternative term sequence.
} 
Table 2: Examples of trisyllabic idioms

\begin{tabular}{|c|c|}
\hline Idiomatic expression & Metaphorical meaning \\
\hline $\begin{array}{lll}\text { yi:u }^{55} & \text { ha:i } & \text { ca:u }^{55} \\
\text { riuj } & \text { haiz } & \text { cauj } \\
\text { carry } & \text { shoes } & \text { straw }\end{array}$ & $\begin{array}{l}\text { 'be an assistant of somebody' } \\
\text { (carry straw sandals for somebody) }\end{array}$ \\
\hline $\begin{array}{lll}\text { king }^{55} & \text { pom }^{33} & \text { lon }^{33} \\
\text { gingj } & \text { boemx } & \text { loengx } \\
\text { roll } & \text { bamboo } & \text { basket }\end{array}$ & $\begin{array}{l}\text { 'boast, or brag about' } \\
\text { (too strong or too powerful to roll } \\
\text { bamboo basket) }\end{array}$ \\
\hline
\end{tabular}

\section{Polysyllabic idioms}

Polysyllabic idioms are expressions consisting of four or more words which are not interpreted literally, Semantically, the meanings of polysyllabic idioms in Zhuang cannot be derived from the sum of their component parts; rather, they must be interpreted as a whole. Every polysyllabic idiom has a surface meaning which is not its real implication. Its real meaning lies inside the polysyllabic idiom. For example the literal meaning of the polysyllabic idiom $\left[\mathrm{ma}^{24}\right.$ ta: $\mathrm{i}^{24} \mathrm{mat}^{55} \mathrm{cai}^{42}$ ta: $\left.\mathrm{i}^{24}\right] \mathrm{ma}$ dai maet caez dai 'dog, die, flea, together, die' is 'if the dog dies, the flea on the dog dies', but its metaphorical meaning is 'we perish together'. Syntactically, polysyllabic idioms have a fixed inherent structure. That is, the structure of a Zhuang polysyllabic idiom is fixed, the order of the constituent elements cannot be arbitrarily changed, and its constituent elements cannot be arbitrarily replaced, added to, or deleted. The polysyllabic idiom $\left[\mathrm{ma}^{24} \mathrm{ta}^{2} \mathrm{i}^{24} \mathrm{mat}^{55} \mathrm{Cai}^{42}\right.$ ta: $\left.: \mathrm{i}^{24}\right] \mathrm{ma}$ dai maet caez dai given above, for example, cannot be recast with the order $\left[\mathrm{mat}^{55} \mathrm{ta}^{2} \mathrm{i}^{4}\right.$ $\mathrm{ma}^{24} \mathrm{cai}^{42} \mathrm{ta}^{24} \mathrm{i}^{24}$ maet dai ma caez dai, nor can an element be added as $\left[\mathrm{ma}^{24}\right.$ ta: $\mathrm{i}^{24}$ mat ${ }^{55} \mathrm{cai}^{42}$ ta: $\left.\mathrm{i}^{24} \mathrm{lo}\right]^{5}$ ma dai maet caez dai $l o$, nor can any part of it be replaced with another word, such as in $\left[\mathrm{mou}^{24}\right] \mathrm{mou}$ 'pig' $\left[\mathrm{ta}: \mathrm{i}^{24} \mathrm{mat}^{55} \mathrm{Cai}^{42}\right.$ ta: $\left.\mathrm{i}^{24}\right]$ dai maet caez dai. Similarly, it cannot be reduced to $\left[\mathrm{ma}^{24} \mathrm{ta}^{2 i^{24}} \mathrm{mat}^{55}\right.$ ta: $\left.\mathrm{i}^{24}\right]$ ma dai maet dai. Polysyllabic idioms are also known as set phrases. Polysyllabic idioms may be grouped into four types based on the number of syllables: tetrasyllabic idioms, pentasyllabic idioms, hexasyllabic idioms, and heptasyllabic idioms, as shown in Table 3 .

\footnotetext{
${ }^{5}[10]$ is a modal particle placed at the end of a sentence to indicate changed circumstances or affirmation.
} 
Table 3: Examples of polysyllabic idioms

\begin{tabular}{|c|c|c|}
\hline Number of syllable & Idiomatic expression & Metaphorical meaning \\
\hline \multirow[t]{3}{*}{$\begin{array}{l}\text { Four } \\
\text { syllables }\end{array}$} & $\begin{array}{llll}\operatorname{tup}^{21} & \mathrm{ku}^{24} & \text { fo: } \mathrm{y}^{24} & \text { ye: } \mathrm{k}^{44} \\
d u b & \mathrm{gu} & \text { fong } & \text { rek } \\
\text { break } & \text { pot } & \text { mend } & \text { pan }\end{array}$ & $\begin{array}{l}\text { 'resort to a stopgap measure } \\
\text { detrimental to long-term } \\
\text { interests' }\end{array}$ \\
\hline & $\begin{array}{llll}\mathrm{ku}^{21} & \text { cak }^{21} & \operatorname{\theta im}^{24} & \mathrm{ti}^{44} \\
\text { guh } & \text { caeg } & \text { sim } & \text { diuq } \\
\text { do } & \text { thief } & \text { heart } & \text { beat }\end{array}$ & 'have a guilty conscience' \\
\hline & $\begin{array}{llll}\text { pai }^{24} & \mathrm{na}^{55} & \text { jaw }^{55} & \text { laq }^{24} \\
\text { bae } & \text { naj } & \text { yawj } & \text { laeng } \\
\text { go } & \text { front } & \text { look } & \text { back } \\
\end{array}$ & $\begin{array}{l}\text { 'be overcautious and } \\
\text { indecisive' }\end{array}$ \\
\hline \multirow[t]{2}{*}{$\begin{array}{l}\text { Five } \\
\text { syllables }\end{array}$} & $\begin{array}{llll}\text { cuk }^{21} & \text { yi: } \mathrm{y}^{24} & \mathrm{ma}^{33} & \text { to }^{33} \text { tik }^{55} \\
\text { cug } & \text { rieng } & \text { max } & \text { doxdik } \\
\text { tie } & \text { tail } & \text { horse } & \text { kick each other }\end{array}$ & $\begin{array}{l}\text { 'incite one to fight the } \\
\text { other' }\end{array}$ \\
\hline & $\begin{array}{lllll}\text { Oai }^{55} & \text { hum }^{42} & \text { Pbou }^{55} & \text { Pdai }^{55} & \mathrm{kau}^{21} \\
\text { saej } & \text { humz } & \text { mbouj } & \text { ndaej } & \text { gaeu } \\
\text { intestines } & \text { itch } & \text { not } & \text { can } & \text { scratch } \\
\end{array}$ & 'have no way out' \\
\hline \multirow[t]{2}{*}{$\begin{array}{l}\text { Six } \\
\text { syllables }\end{array}$} & 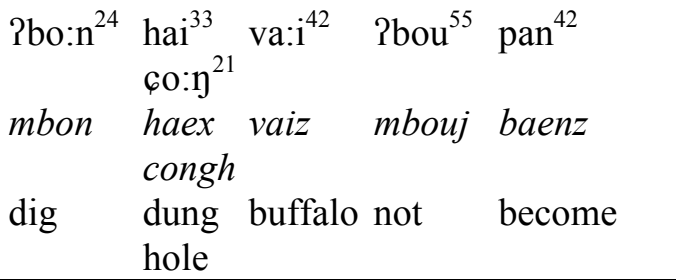 & 'incompetent' \\
\hline & $\begin{array}{lll}\text { Pdok }^{55} & \text { cak }^{55} & \text { Pdok }^{55} \\
\text { ndoek } & \text { caek } & \text { ndoek, } \\
\text { catfish in pond just be } & \text { catfish in pond } \\
\text { ha:u } & \text { cak }^{35} & \text { ha:u } \\
\text { haux } & \text { caek } & \text { haux } \\
\text { catfish in river } & \text { just be } & \text { catfish in river } \\
\end{array}$ & 'a fool never becomes wise' \\
\hline \multirow[t]{2}{*}{$\begin{array}{l}\text { Seven } \\
\text { syllables }\end{array}$} & $\begin{array}{lllll}\text { vun }^{42} & \text { la: }{ }^{24} & \text { tum }^{44} & \text { kjau }^{55} & \text { va:i }{ }^{42} \\
\text { vunz } & \text { lai } & \text { dumq } & \text { gyaeuj } & \text { vaiz } \\
\text { people } & \text { many } & \text { cook } & \text { head } & \text { buffalo } \\
\text { Pbou } & \text { cuk } & & & \\
\text { mbouj } & \text { cug } & & & \\
\text { not } & \text { done } & & & \\
\end{array}$ & $\begin{array}{l}\text { 'too many cooks spoil the } \\
\text { broth' }\end{array}$ \\
\hline & 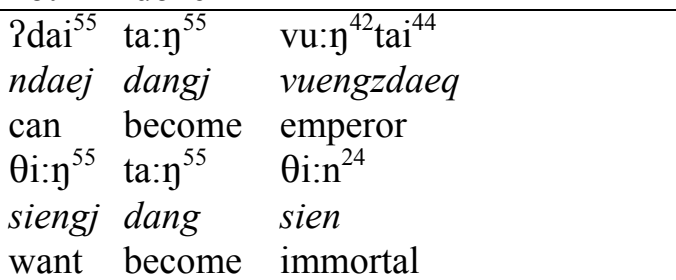 & 'be unsatisfied' \\
\hline
\end{tabular}


The tetrasyllabic idioms occur most frequently. Previous studies of other Tai languages have focused on tetrasyllabic idioms, which are known variously as four-syllable elaborate expressions or four-word elaborate expressions. Amara (2008) studied four-word elaborate expressions in Yunnan Tai Lue. She found that the four-word elaborate expressions were phonologically marked by repetition, rhyme, and alliteration. Semantically, each four-word elaborate expression was split into two parallel semantic units, and the meaning of the whole elaborate expression was idiomatic. Four-word elaborate expressions in Zhuang have characteristics similar to those of Tai Lue. Though rhyming is not typical of tetrasyllabic idioms in Zhuang, reduplication and alliteration are also found, as seen in Table 4.

Table 4: Examples of reduplication and alliteration

\begin{tabular}{|c|c|c|c|c|}
\hline Phonological characteristic & Idiomatic expr & ession & & Metaphorical meaning \\
\hline Reduplication & $\begin{array}{ll}\frac{\text { te:m}^{24}}{\text { dem }^{24}} & \begin{array}{l}\text { kjau } \\
\text { gyaeu } \\
\text { head }\end{array}\end{array}$ & $\frac{\frac{\text { te:m }}{\text { dem }}^{24}}{\frac{\text { add }}{d d}}$ & $\begin{array}{l}\text { yi: }{ }^{24} \\
\text { rieng } \\
\text { tail }\end{array}$ & 'embellish a story' \\
\hline Alliteration & $\begin{array}{ll}\text { Pe:p } \mathrm{p}^{44} & \text { me:u } \\
\text { ep } & \text { meuz } \\
\text { force } & \text { cat }\end{array}$ & $\begin{array}{l}\text { kun }^{24} \\
g w n \\
\text { eat }\end{array}$ & $\begin{array}{l}\text { mei }^{44} \\
\text { meiq } \\
\text { vinegar }\end{array}$ & $\begin{array}{l}\text { 'try to make somebody do } \\
\text { something which s/he won't } \\
\text { or can't do' }\end{array}$ \\
\hline
\end{tabular}

The first idiom shows a reduplication of the word $\left[\right.$ te: $\left.\mathrm{m}^{24}\right] \mathrm{dem}$ 'add'. The second idiom has two words, [me: $\left.\mathrm{u}^{42}\right]$ meuz 'cat' and $\left[\mathrm{mei}^{44}\right]$ meiq 'vinegar', which share the same initial sound $[\mathrm{m}]$.

Another feature shared by Tai Lue and Zhuang is the figurative or metaphorical meaning of four-word expressions. That is, the meanings of the expression must be interpreted as a whole and have to be learned as a whole through cultural transmission.

Amara (2008) has also affirmed that, syntactically speaking, four-word elaborate expressions in Tai Lue are words, not phrases or clauses, for several reasons; (1) the positions of the four words cannot be shifted, (2) none of the words can be left out, (3) the elaborate expression cannot be interrupted by any word, and (4) the elaborate expression is used as a single word. This paper likewise considers Zhuang idioms as a single word for the same reasons.

Luo (1999) studied four-syllable expressions in Tai Dehong. As is the case in Zhuang, some of these Dehong expressions had gained the status of set phrases, while others behaved more like freely combined items. Luo also found rhyme in the idioms. He noted that the rhyming "follows from the traditional practice of Tai people chanting folk songs or poems in which the favored poetic form is 'link rhymes', a practice which is still much preserved in many Tai dialects today" (1999: xxiii). In addition to discussing Tai Dehong, Luo (2008) makes a brief statement concerning 
tetrasyllabic idiomatic expressions in Zhuang, explaining that such elaborate expressions often carry rich cultural connotations. The same can be said of the Zhuang elaborate expressions considered in the present study.

Owing to the common occurrence of foursyllable expressions in Tai languages, Amara (2008: 402) concludes that "the occurrence of four-word expressions is a common feature in Tai language and culture" and, as four-word expressions evince the typical characteristics of verse, idiomaticity, and redundancy, it can be said that "Tai people value rhetoric ability, metaphor, and wordiness in their speech."

In addition to the Tai languages mentioned above, other languages in Southeast Asia make use of such elaborate expressions. Kanchana (1976) notes that four-word expressions are commonly found in Khmer and Thai. Nguyen Dang Liem (1970) has also found that tetrasyllabic idiomatic expressions are very frequent in Vietnamese. These tetrasyllabic idiomatic expressions are often used in ordinary conversation as well as in sophisticated literary writing. Vietnamese elaborate expressions are of either Chinese origin or pure Vietnamese origin. It is well known that tetrasyllabic elaborate expressions have been a favored feature in Chinese writing since the beginning of Chinese literature. Nguyen Dang Liem (1970: 2) remarks that "In Chinese literature, foursyllable expressions, often constructed with parallelism and symbolism, can be traced to early times, as, for instance, to the Han or Tang dynasties. The same literary form is often found in Vietnamese poems." Tetrasyllabic idiomatic expressions not only provide students of Vietnamese with more insight into the morphology and syntax of the language but also give valuable information about Vietnamese culture.

As tetrasyllabic idiomatic expressions are found in languages from different language families, they may be considered a regional linguistic feature of Southeast Asia. If areal diffusion of this feature has occurred, it would be worth investigating its source.

\section{Syntactic patterns}

Trisyllabic idioms are distinguished from polysyllabic idioms by their internal syntactic structures, as discussed below.

\section{Syntactic pattern of trisyllabic idioms}

Trisyllabic idioms have a simple syntactic pattern. They consist of a verb and an object, as exemplified in Table 5. 
Table 5: Examples of the syntactic pattern of trisyllabic idioms

\begin{tabular}{|c|c|c|}
\hline \multicolumn{2}{|c|}{ Syntactic pattern } & \multirow{2}{*}{ Metaphorical meaning } \\
\hline Verb & Object & \\
\hline \begin{tabular}{|l} 
jok $^{55}$ \\
yoek \\
stir
\end{tabular} & $\begin{array}{ll}\text { Уo:1 } & \operatorname{tin}^{42} \\
\text { rong } z & \operatorname{dinz} \\
\text { nest } & \text { wasp }\end{array}$ & 'be greatly offended by' \\
\hline $\begin{array}{l}\theta \mathrm{au}^{55} \\
\text { saeuj } \\
\text { shake }\end{array}$ & $\begin{array}{|ll|}\text { na:1 }^{55} & \text { noy }^{44} \\
\text { nyangj } & \text { nyoengq } \\
\text { straw mess } & \text { mess }\end{array}$ & 'flattery' \\
\hline $\begin{array}{l}\text { kut }^{21} \\
\text { gwed } \\
\text { shoulder }\end{array}$ & $\begin{array}{ll}\mathrm{kjau}^{55} & \mathrm{\gamma o}^{42} \\
\text { gyaeuj } & \text { roz } \\
\text { head } & \text { thin }\end{array}$ & 'be responsible for some charge' \\
\hline $\begin{array}{l}\text { kun }^{24} \\
\text { gwn } \\
\text { eat }\end{array}$ & $\begin{array}{|ll|}\text { hau }^{33} & \text { yo: } \mathrm{k}^{21} \\
\text { haeux } & \text { rog } \\
\text { rice } & \text { outside }\end{array}$ & 'work somewhere away from home' \\
\hline $\begin{array}{l}\text { pjoy }^{44} \\
\text { byoengq } \\
\text { open }\end{array}$ & \begin{tabular}{|ll} 
ha: $y^{33}$ & $\mathrm{ai}^{42}$ \\
hangx & saez \\
bottom & fish trap
\end{tabular} & 'dig up somebody's unsavory past' \\
\hline $\begin{array}{l}\text { po }^{44} \\
\text { boq } \\
\text { blow }\end{array}$ & \begin{tabular}{|ll}
$\mathrm{lo}^{33}$ & $\mathrm{le}^{42}$ \\
lox & lez \\
suona & horn
\end{tabular} & 'smoke the home-made roasted tobacco' \\
\hline
\end{tabular}

\footnotetext{
${ }^{6}$ This trisyllabic idiom has the literal meaning 'to blow a reed trumpet (suona horn)' but its' metaphorical meaning is 'to smoke home-made roasted tobacco' which has a shape similar to a reed trumpet'.
} 


\section{Syntactic pattern of polysyllabic idioms}

Polysyllabic idioms in Zhuang have a more complex syntactic pattern than trisyllabic idioms. Based on their internal syntactic patterns, polysyllabic idioms may be analyzed as having four different syntactic patterns: serial, causative, topicalized, and condensed.

\section{Serial pattern}

The serial pattern consists of a sequence of juxtaposed separate verbs sharing the same subject without the overt use of conjunctions. Table 6 provides examples of polysyllabic idioms with serial construction. The underlined verbs constitute the serial pattern.

Table 6: Examples of the serial pattern

\begin{tabular}{|c|c|c|c|c|}
\hline \multicolumn{4}{|c|}{ Serial construction } & Metaphorical meaning \\
\hline \multirow{3}{*}{$\begin{array}{l}{\frac{\text { to }^{33} \text { tu: }^{21}}{\text { doxduengh }}}_{\text {drag each other }} \\
\text { drat }\end{array}$} & yon $^{42}$ & $\operatorname{van}^{42}$ & & 'perish together' \\
\hline & roengz & vaengz & & \\
\hline & down & deep river & & \\
\hline$\underline{10}^{21} \mathrm{ka}: \mathrm{\eta}^{21}$ & $\mathrm{pai}^{24}$ & tukk $^{55} \operatorname{tin}^{42}$ & & 'having plenty of guts' \\
\hline lohgengh & $\underline{\text { bae }}$ & $\operatorname{din} z$ & & \\
\hline barebacked & go & attack wasp & & \\
\hline$\underline{\mathrm{Pau}}^{24}$ jou $^{42}$ & $\underline{\operatorname{tau}}^{55}$ & ce: $u^{55} \quad \mathrm{ve}^{24}$ & va: $i^{42}$ & 'the loss outweighs the gain' \\
\hline youz & daeuj & ceuj & vaiz & \\
\hline get & come & hoof & buffalo & \\
\hline
\end{tabular}

\section{Causative pattern}

The causative pattern deals with the notion of making something happen. It consists of a verb followed by an object which concurrently acts as the subject of a subsequent predicate word group, as exemplified in Table 7. All examples in Table 7 have an agent which is left out but understood to be "someone". The initial verbs are the causative verbs. These are followed by their objects which then function as the subjects of the verbs that follow.

Table 7: Examples of the causative pattern

\begin{tabular}{|c|c|c|c|c|}
\hline \multicolumn{4}{|c|}{ Causative pattern } & \multirow{2}{*}{$\begin{array}{l}\text { Metaphorical meaning } \\
\text { 'try to make somebody do something which } \\
\text { s/he won't or can't do' }\end{array}$} \\
\hline $\begin{array}{l}\text { Pe:p } p^{44} \\
e p \\
\text { force }\end{array}$ & $\begin{array}{l}\text { me: } \mathrm{u}^{42} \\
\text { meuz } \\
\text { cat }\end{array}$ & $\begin{array}{l}\text { kun }^{24} \\
g w n \\
\text { eat }\end{array}$ & $\begin{array}{l}\text { mei }^{44} \\
\text { meiq } \\
\text { vinegar }\end{array}$ & \\
\hline $\begin{array}{l}P a: u^{24} \\
a u \\
\text { call }\end{array}$ & $\begin{array}{l}m a:^{24} \\
m a \\
\operatorname{dog}\end{array}$ & $\begin{array}{l}\text { to } \\
\text { dox } \\
\text { bite }\end{array}$ & $\begin{array}{l}\text { hap }^{21} \\
\text { haeb } \\
\text { each other }\end{array}$ & 'incite one against the other' \\
\hline
\end{tabular}




\begin{tabular}{|c|c|c|c|c|}
\hline \multicolumn{4}{|c|}{ Causative pattern } & \multirow{2}{*}{$\begin{array}{l}\text { Metaphorical meaning } \\
\text { 'look for trouble }\end{array}$} \\
\hline $\begin{array}{l}\text { nap }^{21} \\
\text { nyaeb } \\
\text { pick }\end{array}$ & $\begin{array}{l}\text { mat }^{55} \\
\text { maet } \\
\text { flea }\end{array}$ & $\begin{array}{l}\text { hau }^{55} \\
\text { haeuj } \\
\text { get in }\end{array}$ & $\begin{array}{l}\text { Pda: }{ }^{24} \\
\text { ndang } \\
\text { body }\end{array}$ & \\
\hline $\begin{array}{l}\text { la: }{ }^{21} \\
\text { langh } \\
\text { put }\end{array}$ & $\begin{array}{l}\text { pit }^{55} \\
\text { bit } \\
\text { duck }\end{array}$ & $\begin{array}{l}\text { yon }^{42} \\
\text { roeng } \\
\text { down }\end{array}$ & $\begin{array}{l}\text { yam }^{33} \\
\text { raemx } \\
\text { water }\end{array}$ & 'be just what one hopes for' \\
\hline
\end{tabular}

\section{Topicalized pattern}

The topicalized pattern has a topic which may be realized as a grammatical subject or a preposed topicalized element as exemplified in Table 8 . The first example has the preposed topicalized words [?daw ${ }^{24} \mathrm{ho}^{42}$ ] 'inside throat' as the topic, whereas the following examples have $\left[\mathrm{Pbon}^{24} \mathrm{kju}^{24}\right]$ 'jar of salt' and $\left[\mathrm{mok}^{21} \mathrm{kjan}^{21}\right]$ 'club', which are simultaneously the grammatical subjects and the topics of their respective sentences.

Table 8: Examples of the topicalized pattern

\begin{tabular}{|c|c|c|}
\hline \multicolumn{2}{|c|}{ Topicalized pattern } & \multirow{2}{*}{ Metaphorical meaning } \\
\hline Topic & Predicate word group & \\
\hline $\begin{array}{ll}\text { Pdau } & \text { ho }^{42} \\
\text { ndaw } & \text { hoz } \\
\text { inside } & \text { throat } \\
\end{array}$ & $\begin{array}{ll}\mathrm{mi}^{42} & \text { hai }^{33} \\
\text { miz } & \text { haex } \\
\text { have } & \text { dung } \\
\end{array}$ & 'somebody has a guilty conscience' \\
\hline $\begin{array}{ll}\text { Pbon }^{24} & \mathrm{kju}^{24} \\
\text { mboen } & \text { gyu } \\
\text { jar } & \text { salt } \\
\end{array}$ & $\begin{array}{ll}\text { fa:t } & \text { no: } \mathrm{n}^{24} \\
\text { fat } & \text { non } \\
\text { grow } & \text { worm } \\
\end{array}$ & $\begin{array}{l}\text { 'there is a secret enemy agent within } \\
\text { one's ranks' }\end{array}$ \\
\hline $\begin{array}{l}\text { mok }^{21} \mathrm{kja \eta}^{21} \\
\text { moeggyaengh } \\
\text { club }\end{array}$ & $\begin{array}{lll}\text { Pbou }^{55} & \text { tog }^{42} & \text { yum }^{42} \\
\text { mbouj } & \text { doengz } & \text { rumz } \\
\text { not } & \text { open } & \text { wind }\end{array}$ & 'know nothing about (a subject)' \\
\hline
\end{tabular}

\section{Complement pattern}

Complement is defined by Trask (1993: 51) as "Any constituent which forms part of the nucleus of a category with a lexical head and which is subcategorized for by that lexical head." The complement pattern consists of a verbal nucleus and its complement, as exemplified in Table 9. The first example has the verb $\left[1 \mathrm{a}: \mathrm{u}^{24}\right]$ 'fear' and $\left[\mathrm{yam}^{33} \mathrm{tum}^{21}\right.$ Pbun $^{24}$ ] 'water flooded the sky' as its complement. The second example has the verb $\left[\mathrm{jau}^{55}\right]$ 'look' and $\left[\mathrm{ma}^{33} \mathrm{to}^{33} \mathrm{tik}^{55}\right]$ 'horses kick each other' as its complement. 
Table 9: Examples of the complement pattern

\begin{tabular}{|c|c|c|c|}
\hline \multicolumn{3}{|c|}{ Complement pattern } & \multirow{2}{*}{ Metaphorical meaning } \\
\hline (Adverbial) & Verb & Complement & \\
\hline & $\begin{array}{l}\text { la: } \mathrm{u}^{24} \\
\text { lau } \\
\text { fear } \\
\end{array}$ & $\begin{array}{lll}\text { yam }^{33} & \text { tum }^{21} & \text { Pbunn }^{24} \\
\text { raemx } & \text { dumh } & m b w n \\
\text { water } & \text { flood } & \text { sky } \\
\end{array}$ & 'groundless fears' \\
\hline \begin{tabular}{|ll} 
kun $^{42}$ & ci: $^{42}$ \\
gwnz & ciengz \\
up & wall \\
\end{tabular} & $\begin{array}{l}\text { jaw } \\
\text { yawj } \\
\text { look }\end{array}$ & $\begin{array}{ll}\mathrm{ma}^{33} & \text { to }^{33} \text { tik }^{55} \\
\text { max } & \text { doxdik } \\
\text { horse } & \text { kick each other }\end{array}$ & $\begin{array}{l}\text { 'watch in safety while others } \\
\text { fight' }\end{array}$ \\
\hline
\end{tabular}

\section{Condensed pattern}

The condensed pattern is formed by reducing two or more full clauses into fewer words. Semantically, the two condensed clauses are related in various ways, such as conditional relation, coordinative relation, or concessive relation, as seen in Table 10. In the three examples below, the initial clause is juxtaposed with the second clauses. Both clauses are reduced to a single condensed pattern.

Table 10: Examples of the condensed pattern

\begin{tabular}{|c|c|c|}
\hline \multicolumn{2}{|c|}{ Condensed pattern } & \multirow[t]{2}{*}{ Metaphorical meaning } \\
\hline Clause 1 & Clause 2 & \\
\hline $\begin{array}{ll}\mathrm{ma}^{24} & \mathrm{ta}^{24} \\
m a & \text { dai } \\
\text { dog } & \text { die } \\
\end{array}$ & $\begin{array}{lll}\text { mat }^{55} & \text { cai }^{42} & \text { ta: }^{24} \\
\text { maet } & \text { caez } & \text { dai } \\
\text { flea } & \text { together } & \text { die } \\
\end{array}$ & $\begin{array}{l}\text { 'perish together' } \\
\text { [conditional relation] }\end{array}$ \\
\hline $\begin{array}{ll}\text { te:m } & \mathrm{kjau}^{55} \\
\text { dem } & \text { gyaeuj } \\
\text { add } & \text { head }\end{array}$ & 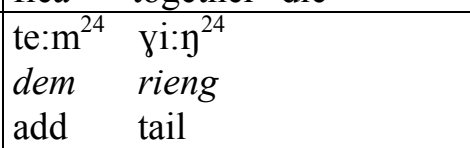 & $\begin{array}{l}\text { 'embellish a story' } \\
\text { [coordinative relation] }\end{array}$ \\
\hline $\begin{array}{ll}\mathrm{ma}^{33} & \mathrm{kan}^{55} \\
\max & \text { gaenj } \\
\text { horse } & \text { rapid }\end{array}$ & $\begin{array}{llll}\text { Pbou }^{55} & \text { 1daj }^{55} & \text { hau }^{55} & \text { Oin }^{42} \\
\text { mbouj } & \text { ndaej } & \text { haeuj } & \text { singz } \\
\text { not } & \text { can } & \text { enter } & \text { city }\end{array}$ & $\begin{array}{l}\text { 'more haste, less speed' } \\
\text { [concessive relation] }\end{array}$ \\
\hline
\end{tabular}

\section{Function of Zhuang idioms}

Idioms in any language, including Zhuang, are concise and vivid. Zhuang idioms are used to increase the effectiveness and rhetorical force of an utterance. An example of this may be seen in the short passage given below. The Zhuang idiom is underlined. 


\begin{tabular}{|c|c|c|c|c|c|c|c|}
\hline $\begin{array}{l}t e^{24} \\
\text { de } \\
3 s g\end{array}$ & $\begin{array}{l}\text { nau }^{42} \\
\text { naeuz } \\
\text { criticize }\end{array}$ & $\begin{array}{l}\text { vun }^{42} \\
\text { vunz, } \\
\text { others }\end{array}$ & $\begin{array}{l}\operatorname{tak}^{55} 60: i^{21} \\
\text { daekcoih } \\
\text { offend }\end{array}$ & $\begin{array}{l}\text { ha:u } \\
\text { haujl } \\
\text { many }\end{array}$ & $\begin{array}{l}55 \text { la: } i^{24} \\
\text { ai }\end{array}$ & $\begin{array}{l}\text { vun }^{42} \\
\text { vunz } \\
\text { people }\end{array}$ & \\
\hline $\mathrm{ki}^{55}$ & $\operatorname{vun}^{42}$ nei $^{33}$ na:n ${ }^{42}$ & $\mathrm{Pbou}^{55}$ & 5 na:n ${ }^{42} \quad \mathrm{Pau}^{24}$ & $\operatorname{yin}^{24}$ & vit $^{55}$ & huun $^{55}$ & kuun $^{42}$ \\
\hline $\begin{array}{l}\text { gij } \\
\text { these }\end{array}$ & $\begin{array}{lll}\text { vunz } & \text { neix } & \text { nanz } \\
\text { people } & \text { this } & \text { long }\end{array}$ & $\begin{array}{l}\text { mbouj } \\
\text { not }\end{array}$ & $\begin{array}{l}\text { nanz } \\
\text { long }\end{array}$ & $\begin{array}{l}\text { rin } \\
\text { stone }\end{array}$ & $\begin{array}{l}\text { vit } \\
\text { throw }\end{array}$ & $\begin{array}{l}h w n j \\
\text { up }\end{array}$ & $\begin{array}{l}g w n z \\
\text { above }\end{array}$ \\
\hline $\mathrm{va}^{33}$ & $\mathrm{pai}^{24} \mathrm{me}^{21} \mathrm{ja}^{21}$ & $\mathrm{te}^{24}$ & Pda:t ${ }^{44}$ hei $^{44}$ ya:i & ${ }^{33} \mathrm{Cai}^{33}$ & $\operatorname{nau}^{42}$ & $\mathrm{te}^{24}$ & \\
\hline $\begin{array}{l}\text { vax } \\
\text { tile }\end{array}$ & $\begin{array}{l}\text { de bae mehyah } \\
3 \mathrm{sg} \text { to } \text { wife }\end{array}$ & $\begin{array}{l}d e \\
3 \mathrm{sg}\end{array}$ & $\begin{array}{l}\text { ndatheiq } \\
\text { angry }\end{array}$ & caix, & $\begin{array}{l}\text { naeuz } \\
\text { criticize }\end{array}$ & $\begin{array}{l}d e: \\
3 \mathrm{sg}\end{array}$ & \\
\hline $\operatorname{yan}^{24}$ & $\mathrm{Pbou}^{55} \mathrm{Ca \eta}^{42}$ & & $\mathrm{mat}^{55}$ & $\mathrm{hau}^{55}$ & $2 \mathrm{da}: \eta^{24} 1$ & lo & \\
\hline $\begin{array}{l}\text { "Rae } \\
\text { see }\end{array}$ & $\begin{array}{l}\text { mboujcaengz, } \\
\text { not yet }\end{array}$ & & $\begin{array}{ll}\text { nyaeb maet } \\
\text { pick } & \text { flea }\end{array}$ & $\begin{array}{l}\text { haeuj } \\
\text { get ints }\end{array}$ & $\begin{array}{l}\text { ndang } \\
\text { body } 1\end{array}$ & $\begin{array}{l}l o . " \\
\bmod \end{array}$ & \\
\hline
\end{tabular}

'He liked criticizing others, which offended many people. These people often tossed stones on the tile roof of his house. His wife was very angry and blamed him, "Haven't you seen that? You have invited fleas onto your body.",

In this short excerpt, the author uses the idiom $\left[\right.$ nap $^{21} \mathrm{mat}^{55}$ yoy ${ }^{42}$ ?da: $\left.\mathrm{n}^{24}\right]$ nyaeb maet haeuj ndang 'ask for trouble' to express the anger and blame of the wife, depicting the characteristic argumentativeness of her husband's nature very tersely and vividly and thereby achieving good rhetorical results.

\section{Conclusion}

This paper ${ }^{7}$ describes Zhuang idioms found in the northern variety of the Zhuang language. Based on their

\footnotetext{
${ }^{7}$ This paper forms a part of the Northern Zhuang-Chinese-Thai-English Dictionary (Qin and Somsonge 2006) which has been revised for journal publication. We thank Richard Hiam for editing the first draft of the paper. We are also grateful to Professor Wei Jingyun, a native speaker of Northern Zhuang, and Professor Zhou Guoyan for providing us with additional data.
}

syntactic structure, Zhuang idioms are analyzed into two major types, trisyllabic idioms and polysyllabic idioms. Trisyllabic idioms are fixed and short common expressions consisting of a single predicate. Polysyllabic idioms are grouped into four types based on the number of syllables:, tetrasyllabic idioms, pentasyllabic idioms, hexasyllabic idioms, and heptasyllabic idioms. Syntactically, polysyllabic idioms comprise four syntactic patterns: serial, causative, topicalized, and condensed. Zhuang idioms are viewed as a single word group. Semantically, the full meaning of a Zhuang idiom is figurative or metaphorical. The function of Zhuang idioms is to increase effectiveness and rhetorical force in oral and literary communication.

\section{References}

Amara Prasithrathsint. 2008. Four-Word Elaborate Expressions in Yunnan Tai Lue: A Pan-Tai Cultural Trait? In The Tai-Kadai Languages, ed. by Anthony V. N. Diller, Jerold Edmondson, and 
Yongxian Luo, pp. 395-403.

London and New York: Routledge.

Crystal, David. 1985. A Dictionary of Linguistics and Phonetics. Oxford: Blackwell.

Kanchana Nacaskul. 1976. Types of Elaboration in Some Southeast Asian Languages. In Austroasiatic Studies, Part II (Oceanic Linguistics Special Publication No. 13.), ed. by Philip N. Jenner, Laurence C. Thompson, and Stanley Starosta, pp. 873-889. Honolulu: University of Hawaii Press.

Luo Yongxian. 1999. A Dictionary of Dehong Southwest China. Canberra: ANU Printing Service.

Luo Yongxian. 2008. Zhuang. In The Tai Kadai Languages, ed. by Anthony V.N. Diller, Jerold Edmondson, and Yongxian Luo, pp. 317-377. Londonand New York: Routledge.

Nguyen Dang Liem. 1970. FourSyllable Idiomatic Expressions in Vietnamese. Canberra: ANU Printing Service.

Qin Xiaohang. 1995. Modern Zhuang Language. Beijing: Publishing House of the Central Institute for Nationalities.
Somsonge Burusphat and Qin Xiaohang. 2006. Northern ZhuangChinese Thai English-Dictionary. Bangkok:

Ekphimthai.

Trask, R.L. 1993. A Dictionary of Grammatical Terms in Linguistics. London and New York: Routledge. 